\title{
ON THE NECESSITY TO CREATE A NATIONAL PROCESSING CENTRE
}

\author{
Andriy BIRYUKOV, Oleksandr GORDIEIEV, \\ and Oleksandr YAKIMENKO
}

\begin{abstract}
The wide spread of Visa and Master Card international payment systems and the absence of a national processing centre in Ukraine adversely affect the development of the country's banking system and cause further problems. This article gives a brief description of the problems and suggests measures towards their solution.
\end{abstract}

Keywords: Processing centre, bank clearing, payment systems, bank card, credit card.

\section{Introduction}

Banking payment plastic cards (further plastic cards) have received widespread application in the world. The demand for their use is growing every year. ${ }^{1} \mathrm{~A}$ similar dynamics is observed in Ukraine (Table 1).

The work of plastic cards is provided and maintained by the relevant payment system. Payment System is an association of banks and companies operating under the gen-

Table 1. The growth of payment cards market indicators, $2002-2010$.

\begin{tabular}{lccc}
\hline \multicolumn{1}{c}{ Indicator } & $\mathbf{2 0 0 2}$ & $\mathbf{2 0 1 0}$ & Growth \\
\hline Number of participating banks & 58 & 146 & 2.5 times \\
Number of Payment Cards & $3.6 \mathrm{M}$ & $29.1 \mathrm{M}$ & 8 times \\
Number of ATMs & $1.8 \mathrm{~K}$ & $28.9 \mathrm{~K}$ & 15.8 times \\
Number of payment terminals & 14.8 & 103.1 & 7.1 times \\
Number of operations & 74 & 590 & 8 times \\
Volume of transactions & $20 \mathrm{~B} \mathrm{UAH}$ & $353.2 \mathrm{~B} \mathrm{UAH}$ & 17.6 times \\
\hline
\end{tabular}


eral rules of cards. The basis of the payment system is the set of regulatory, contractual, financial and information technology, and solutions of participants, that govern their relationship regarding the order use of cards. ${ }^{2}$ All cards that belong to the same payment system, have signs that identify them as belonging to this payment system.

On the territory of Ukraine, international payment systems such as Visa, Master Card, National Payment System NSMEP (National system of mass electronic payments) are used. Due to some reasons, which we haven't described in this article, in the banking system of Ukraine Visa and Master Card are more popular than NSMEP. Technical support and processing of payment systems are provided by the appropriate processing centres. Processing is an activity that involves handling and storage of information for payments, entering and editing information, database management of the products and internal production. ${ }^{3} \mathrm{We}$ often use this "processing" term in the sphere of banking payment cards. The processing centre is a legal entity or it's organizational department, that provides information and technological cooperation between the payment participants. ${ }^{4}$

Each commercial bank which is a participant of the payment system (issuing bank), emits plastic cards and is named issuing bank. A commercial bank offering a full range of operations in the interaction with the network card service, which consists of ATMs and terminals in the trade and service network is called acquiring bank. ${ }^{5}$

\section{Problem Statement}

International payment system in Ukraine is the dominant, because 36,8 million from 42,2 million cards payment - cards payment of international cards payment. The volume of international operations with payment cards is only $0.7 \%$ of general volume, $2.4 \%$ of all operations with plastic cards. The predominance of international payment systems in the banking system of Ukraine has the following consequences:

1. The amount of commission paid by Ukrainian banks for international payment systems account for 35 million dollars;

2. The amount of insurance of deposits, calculated by international payment systems is about $\$ 110$ million;

3. Since 2008 there is a significant annual increase in fees by international payment systems;

4. Banks are notified of significant increase in the insurance of deposits.

Let's correlate the causes for dominance of international payment systems in Ukraine with potential consequences for the banking system, and for the state as a whole (see Table 2). 
Table 2. Interconnection of the causes and consequences of dominance of the international payment systems in Ukraine.

\begin{tabular}{|c|c|c|}
\hline \# & Cause & Consequence \\
\hline 1 & $\begin{array}{l}\text { The absence in Ukraine full opera- } \\
\text { tional and billing cycle - processing } \\
\text { (routing, authorization, clearing, } \\
\text { settlement with banks) }\end{array}$ & $\begin{array}{l}\text { Interbank clearing between commercial } \\
\text { banks of Ukraine are carrying out } \\
\text { abroad in the Visa and Master Card } \\
\text { processing centre }\end{array}$ \\
\hline 2 & $\begin{array}{l}\text { International payment systems are } \\
\text { not registered in Ukraine as a legal } \\
\text { entity }\end{array}$ & $\begin{array}{l}\text { Taxes from the activities of interna- } \\
\text { tional payment systems in Ukraine, in- } \\
\text { cluding in the interbank clearing, go } \\
\text { into the budget of another state }\end{array}$ \\
\hline 3 & $\begin{array}{l}\text { Interbank clearing between com- } \\
\text { mercial banks of Ukraine are car- } \\
\text { rying out abroad in the Visa and } \\
\text { Master Card processing centre }\end{array}$ & $\begin{array}{l}\text { There is a threat to security of the } \\
\text { banking system of Ukraine }\end{array}$ \\
\hline
\end{tabular}

Marked effects of the predominance of international payment systems in whole or in part can be solved by creating a single Ukrainian National Processing Centre, serving the banking system.

\section{The steps in creating a national processing centre}

The process of creation of a national processing centre, as mentioned by the authors, should be conducted in accordance with the following steps:

1. The formation and implementation of legal and regulatory base that promotes the creation and development of the processing centre;

2. The formation of the organizational structure for the management and control of the processing centre. At this stage it is possible to consider variants of including in the organizational structure of the elements presented in the (Table 3);

3. The formation of requirements, taking into account of European and international experience in creating processing centres;

4. The development of structure and architecture of the processing system, considering necessary level of protections and reliability;

5. The preparation of technical specifications for processing system;

6. Technological realization of the processing system;

7. Tests of the processing technical system;

8. Implementation of the processing technical system. 
Table 3. Organizational structure options of the processing centre.

\begin{tabular}{|c|c|c|c|c|c|c|}
\hline \multirow[t]{2}{*}{ \# } & \multicolumn{2}{|c|}{ Banks of Ukraine } & \multicolumn{4}{|c|}{ Payment systems } \\
\hline & $\mathrm{NBU}$ & $\begin{array}{c}\text { Commercial } \\
\text { banks }\end{array}$ & Visa & NBU & $\begin{array}{c}\text { Commercial } \\
\text { banks }\end{array}$ & $\begin{array}{c}\text { National payment system } \\
\text { compatible with Visa and } \\
\text { Master Card }\end{array}$ \\
\hline 1 & + & + & + & + & - & - \\
\hline 2 & + & + & - & - & + & - \\
\hline 3 & + & + & - & - & - & + \\
\hline 4 & + & + & + & + & - & + \\
\hline 5 & + & - & + & + & - & - \\
\hline 6 & + & - & - & - & + & - \\
\hline 7 & + & - & - & - & - & + \\
\hline 8 & + & - & + & + & - & + \\
\hline 9 & - & + & + & + & - & - \\
\hline 10 & - & + & - & - & + & - \\
\hline 11 & - & + & - & - & - & + \\
\hline 12 & - & + & + & + & - & + \\
\hline \multicolumn{7}{|c|}{$«+»-$ part of the organizational structure } \\
\hline
\end{tabular}

Formation and implementation of legal and regulatory framework conducive to the creation and development of the processing centre

The formation of the regulatory framework that promotes a processing centre includes the study of the existing international experience. In this regard, it was decided to conduct a brief analysis of the experience of the European Union, Russia and the United States of America.

\section{Analysis of foreign legal and regulatory framework in the context of supervision (oversight) for the card payment system}

Analysis of the regulatory framework adopted in the European Union showed that one of the key policy concepts oversight is "Providing management and containment of financial risks that relate to processes of clearing and settlement. This includes identification of financial risks that arise in the process of clearing and settlement mechanisms to use. Implement appropriate measures to eliminate such risks, including the availability of clearing infrastructure in the country." 
The analysis of the regulatory framework in the Russian Federation shows that, in accordance with the bill "On the national payment system" the following activities are carried out:

1. Oversight in accordance with European legislation;

2. Regulation of internal Russian clearing and settlement, including the ability for banks to participate in international payment systems subject to the payment system involving the clearing centre and billing centre, based in the territory of the Russian Federation;

3. Formation of the international payment system in the Russian Federation legal entity, in accordance with Federal law, as well as registration of a legal entity in the registry operators of payment systems.

The analysis of the regulatory framework in the United States of America showed that the US Financial Regulatory Reform Bill, Dodd-Frank Wall Street Reform and the Consumer Protection Act mandate the following:

1. Provision of Financial Stability Oversight Council freedom to determine the system - significant clearing, payment and settlement systems for tighter Federal Reserve regulation;

2. Provision of the Federal Reserve authority to regulate interchange transaction fees, to the size of the commissions was reasonable and proportionate to the actual costs of banks to conduct operations;

3. Provision of the Federal Reserve authority to regulate network fees;

4. Barring payment systems to limit the right to choose a merchant payment network for processing (routing and clearing) operations with payment cards.

Generalizing the results of the analysis of the international legal framework we can say that the overall global trend with respect to oversight of payment systems consists of the following positions:

1. Registration of national regulator of payment systems, rules of payment systems in accordance with the requirements of national legislation and implement procedures for oversight of them;

2. Eliminating the dependence of each state and market participants on the factors and risks that adversely affect its financial security. 


\section{The formation of the legal framework of Ukraine, needed for creation of the National Processing Centre}

In Ukraine there are works on draft law that need to strengthen the position of the national regulator of payment systems and facilitate the establishment of the National Processing Centre. Consider some of them.

Draft law number 6465 "On Amendments to Certain Legislative Acts of Ukraine" (regarding the improvement of mechanisms of functioning of payment systems, and special means of payment in Ukraine). Its purpose is introduction of unified approach to state regulation of national and international payment systems in Ukraine. The adoption of this law would provide for:

- priority development of the national payment space;

- reducing costs of business entities in foreign currency;

- guarantee payments in local and foreign currency reduced commissions that are paid to foreign banks and international card payment system.

Draft law 6466 "On Payment Systems and Funds Transfer in Ukraine" concerns the development of non-cash payments using special means of payment and the National payment space. The main objective of the law is the formation of the groundwork for public policy in the sphere of settlement, with the participation of individuals and in the use of special means of payment among legal entities.

\section{Conclusions and Future Plans}

This work allowed to justify the need for national processing centre. Analysis of the international legal framework has confirmed the need to implement the described draft laws. In the future we plan to implement the following tasks:

- introduction draft laws to the up level laws of Ukraine;

- formulation and solution of organization and technological problems for creation of the National Processing Centre;

- development and implementation of a national EMV (Europay, MasterCard, Visa) compliant card payment system.

\section{Notes:}

1 Statistical Data Warehouse, "Numbered of cards issued in the country," $<$ http://sdw.ecb.europa.eu/reports.do?node=1000001453>(5 June 2011). 
2 Tom Kokkola, The Payment System: Payments, Securities and Derivatives, and the Role of the Eurosystem (Frankfurt: European Central Bank, 2010), 25-64.

3 A.A. Stigak, "The structure of payment systems and modeling their performance based on system analysis," Electronic modeling 6 (2010): 97-109.

4 Card-issuing bank, www.qfinance.com/dictionary/card-issuing-bank (5 June 2011).

5 Payments API, Payments 101: What is an Acquiring Bank? (27 July 2010); <www.paymentsapi.com/2010/07/what-is-acquiring-bank>.

ANDRIY BIRYUKOV, advisor-consultant of The Verkhovna Rada of Ukraine, Ex-head of the Department of informatization and payment systems of the National Bank of Ukraine. Scientific interests: payment cards systems, information technologies in economy.

OLEKSANDR GORDIEIEV, PhD, associate Professor, Head of Mathematics Social Sconces and Humanities Department of Sevastopol Institute of Banking of the Ukrainian Academy of Banking of the National Bank of Ukraine. Dr. Gordieiev has published as author or coauthor more than 30 scientific papers in scientific technical journals and in proceedings of international conference. Scientific interests: software quality assessments, business-critical systems and services, information technologies in economy.

OLEKSANDR YAKIMENKO, assistant professor at the Mathematics Social Sciences and Humanities Department of Sevastopol Institute of Banking of the Ukrainian Academy of Banking of the National Bank of Ukraine. Scientific interests: modeling in economy, information technologies in economy.

Address for correspondence: Social Sconces and Humanities Department of the Sevastopol Institute of Banking of the Ukrainian Academy of Banking of the National Bank of Ukraine, 6 Parkovaya Str., Sevastopol, 99057, Ukraine.E-mail: alex.gordeyev@gmail.com. 